\title{
O REI MAIA KUKULCÁN E SEUS DISCURSOS DE PROPAGANDA POLÍTICA EM CHICHÉN ITZÁ
}

The Mayan King Kukulcan and his Speeches of Political Propaganda in Chichen Itza

\section{Alexandre Guida Navarro ${ }^{1}$}

\section{RESUMO}

Chichén Itzá foi um populoso centro urbano maia responsável por tributar centenas de cidades, organizar um exército eficaz para os empreendimentos guerreiros e realizar comércio de longa distância com outras cidades maias e de outras etnias. Durante seu auge, no século IX, a cidade foi governada por um rei chamado Kukulcán, que foi responsável pela maioria das construções arquitetônicas da cidade. Tal governo foi marcado por uma eficiente propaganda política que foi planejada segundo um processo cognitivo de representação imagética do governante, cuja principal manifestação deu-se em forma de uma serpente emplumada. Estas imagens serviram de propaganda política para perpetuar a soberania deste rei, além de ser um registro imagético de sua importância na memória coletiva desta cidade maia.

Palavras-chave: civilização maia, propaganda política, cultura material

\section{ABSTRACT}

Chichén Itzá was a populated urban center Mayan responsible for taxing hundreds of cities, to organize an army effective for warriors and perform long-distance trade with other Mayan cities and other ethnicities. During its heyday in the ninth century, the city was ruled by a king named Kukulcan, which was responsible for most of the city's architectural constructions. This ruler was marked by an efficient propaganda that was planned according to a cognitive process of his imagery representation, whose main manifestation came in the form of a feathered serpent. These images were used as propaganda to perpetuate the sovereignty of the king, besides being a record imagery of its importance in the collective memory of this Mayan city.
\end{abstract}

Keywords: Mayan Civilization, Political Propaganda, Material Culture

\section{RESUMEN}

Chichén Itzá fue un gran centro urbano maya responsable por tributar cientos de ciudades, organizar un ejército eficaz para y realizar comercio a larga distancia con otras ciudades mayas y otros grupos étnicos. Durante su apogeo en el siglo IX, la ciudad fue gobernada por un rey llamado Kukulcán, que construyó la mayoría de los edificios arquitectónicos de la ciudad. Este gobierno fue marcado por una propaganda eficaz que fue planeada de acuerdo

\footnotetext{
${ }^{1}$ Doutor em Arqueologia pela Universidad Nacional Autónoma de México (UNAM). Professor Adjunto II da Universidade Federal do Maranhão (UFMA). E-mail: altardesacrificios@yahoo.com.br
} 
con un proceso cognitivo bajo la representación de las imágenes del gobernante, cuya principal manifestación era la serpiente emplumada. Estas imágenes fueron utilizadas como propaganda para perpetuar la soberanía del rey, además de ser un registro importante de las imágenes como memoria colectiva de esta ciudad maya.

Palabras clave: civilización maya, propaganda política, cultura material

\section{Introdução: As crônicas}

As crônicas escritas pelos missionários espanhóis no século XVI são um conjunto documental etnográfico acerca das comunidades maias que viviam na Península do Iucatã quando do período do contato. Por outro lado, por associação etnológica, muitos costumes indígenas relatados na época da Conquista foram utilizados para explicar o cotidiano maia de períodos anteriores, como o Clássico (300-900 d.C.), sobretudo os aspectos religiosos, muitos dos quais, teriam sobrevivido à época da chegada dos conquistadores.

O personagem Kukulcán aparece em várias destas crônicas, como o relato do bispo Diego de Landa em sua célebre obra Relación de las cosas de Yucatán (1566). A etimologia da palavra revela que kuk é "pluma de ave geral" e can, "serpente, cobra" (Dicionário maia Cordemex, p. 420, 1980). Portanto, este personagem está associado à serpente emplumada, um importante símbolo religioso pré-hispânico, que, na versão religiosa do altiplano recebeu o nome de Quetzalcóatl.

Qual o seu significado segundo as crônicas? Nestes documentos, uma das associações de Kukulcán refere-se aos assuntos governamentais, e sua relação com a cultura material apareceu pela primeira vez na importante obra do primeiro bispo de Iucatán, frei Diego de Landa, intitulada "Relaciones de las Cosas de Yucatán", quem em 1566 escreveu que “... é opinião que entre os itzaes que povoaram Chicheniza, reinou um grande senhor chamado Cuculcan, e que mostra ser isso verdade que o edifício principal se chama Cuculcan..." (LANDA, 2003: 94). Fica evidente, deste modo, que na obra de Landa, Kukulcán é um soberano maia.

Por outro lado, outros cronistas, como Diego López de Cogolludo (1688) e Bernardo de Lizana (1633) registraram a existência histórica de Kukulcán como um personagem associado à guerra na península do Iucatã. Cogolludo (1688) documenta que “...os itzás de Chichén Itzá veneravam um ídolo que havia sido grande capitão [guerreiro] entre eles, chamando-o de Kukulcan ou serpente emplumada..." (LÓPEZ DE COGOLLUDO, 1971 I: $352)$. 
Já nas Relaciones Histórico-Geográficas de la Gobernación de Yucatán (1984a) [1560], o nome de Kukulcán aparece citado seis vezes, todas elas apontando o personagem como o introdutor da idolatria no Iucatã. A Relación de Motul (1984: 269-70) narra que:

No que toca às adorações tinham conhecimentos de um Deus que criou o céu e a terra e todas as coisas... ao qual tinham edificado templo com sacerdotes, que levavam presentes e esmolas para que eles os oferecessem a Deus, e esta maneira de adoração teve até que veio de fora desta terra um grande senhor com gente chamado Kukulcan, e daqui começaram os da terra idolatrar.

\section{Chichén Itzá e Kukulcán}

Chichén Itzá foi centro hegemônico que conquistou militarmente grande parte da Península do Iucatã, foi produtor e distribuidor exclusivo de sal em toda Mesoamérica, controlou grande parte das rotas marítimas maias através da construção de portos, além de ter sido uma cidade responsável por tributar várias cidades maias, além de outras no altiplano mexicano. O seu principal conjunto de edifícios chama-se Grande Nivelação, uma grande área de construção arquitetônica localizada ao norte da cidade (PIÑA CHÁN, 1980; RINGLE et al. 1998; LÓPEZ AUSTIN e LÓPEZ LUJÁN, 1999; COBOS, 2003; SHARER, 2003; BAUDEZ, 2004; RINGLE, 2004; NAVARRO, 2007).

Embora a escrita de Chichén Itzá não faça alusão direta ao personagem Kukulcán, por analogia etnológica e iconográfica, é possível perceber que este indivíduo foi representado em alguns edifícios da Grande Nivelação (KROCHOCK, 1988, 1989). Levando em consideração a iconografia com temas associados ao poder real na área maia, além de sua associação com a serpente emplumada, o principal componente simbólico de Kukulcán, alguns pesquisadores têm postulado que este personagem foi plasmado na memória coletiva de Chichén Itzá (COBOS, 2003; NAVARRO, 2007; NAVARRO e FUNARI, 2009).

Já que a serpente emplumada é o principal componente iconográfico do personagem, realizamos, através de pesquisa doutoral, um catálogo com a representação destas imagens. Observamos uma considerável variação nos tipos plumários. Em princípio, pensamos que se isso devia ao estilo aplicado pelo pintor, no entanto, essas plumas parecem ser um signo que identifica diferentes conjuntos arquitetônicos dentro da Grande Nivelação. Os exemplares podem ser classificados em: sem plumas, com plumas em forma de gancho, com plumas longas, plumas em forma de espinho e plumas com forma de triângulo isósceles (figuras 1a, 1b, 1c, 1d e 1e; todas desenhadas pelo autor). 

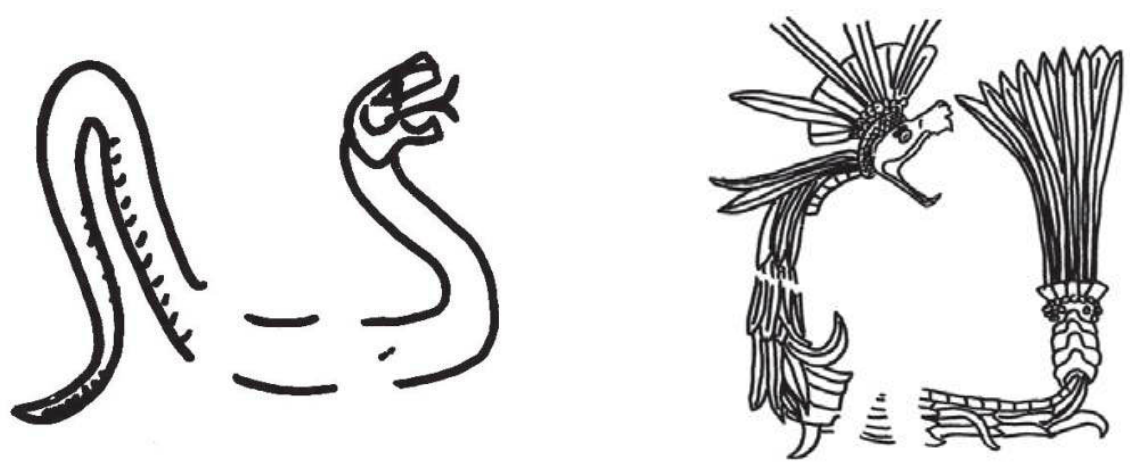

Figura 1a. Serpente sem plumas na serpe

Figura 1b. Serpente com plumas longas.
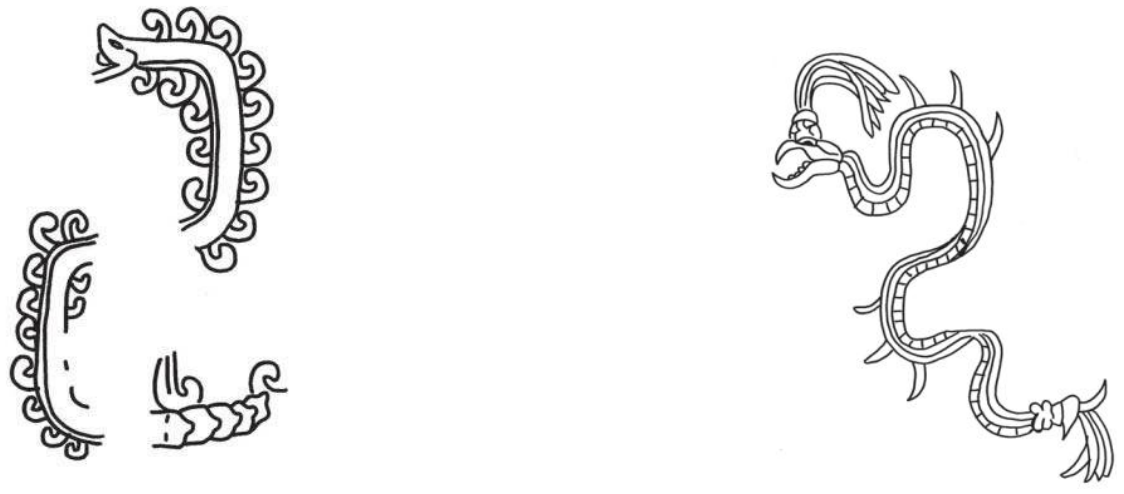

Figura 1c. Serpente com pluma em forma de gancho.

Figura 1d. Serpente com plumas em forma de espinho.

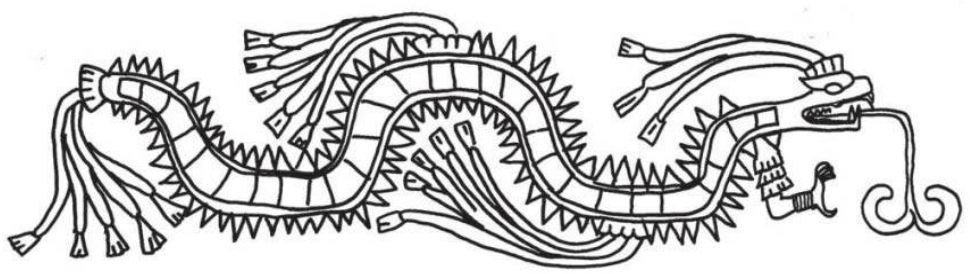

Figura le. Serpente com plumas em forma de triângulo isósceles. 
Catalogado um total de 147 imagens de serpentes com e sem plumas, apenas 10 não estão na Grande Nivelação. Isso significa que 93,19\% das imagens de serpente catalogadas aparece nesta esplanada (figura 2).
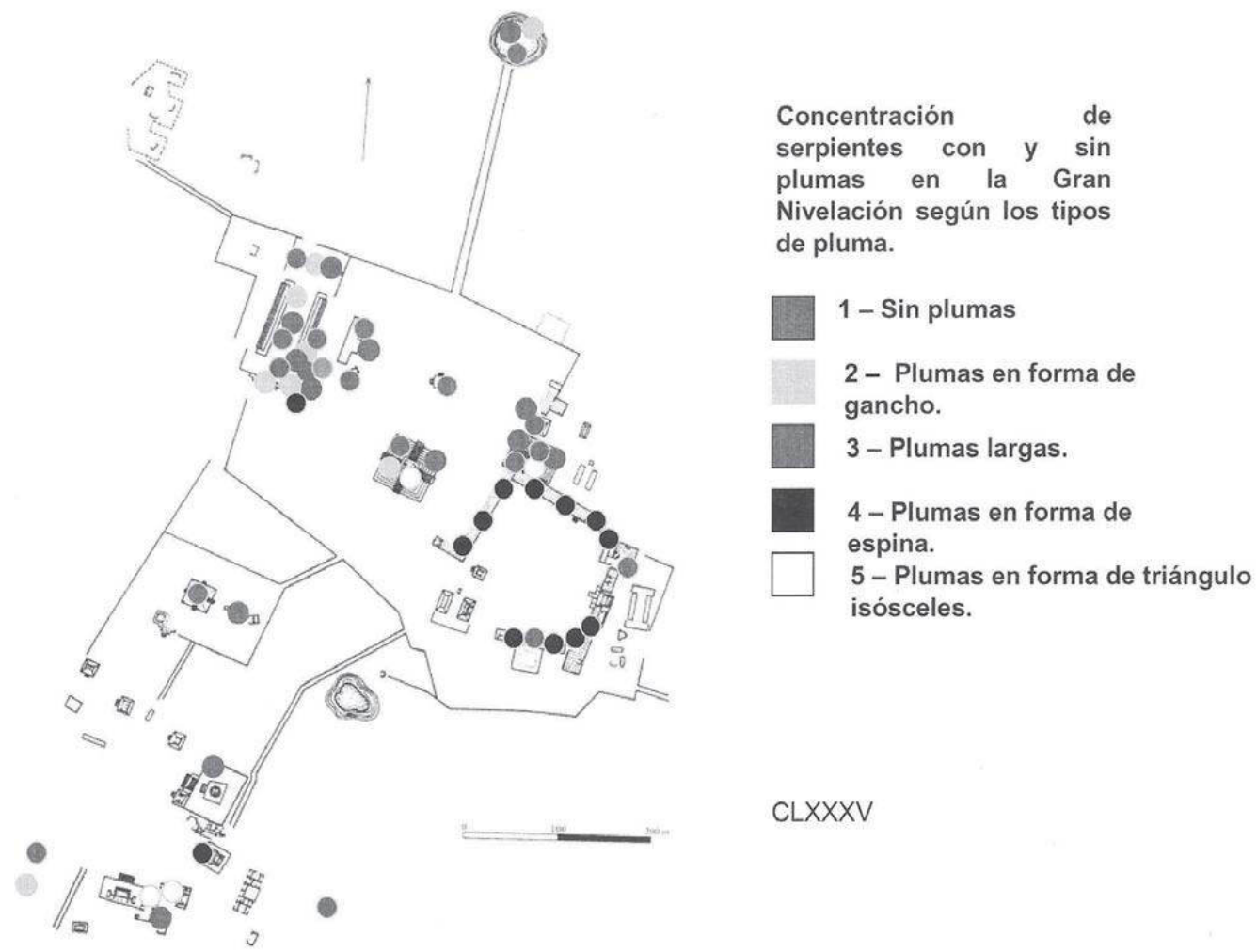

CLXXXV

Figura 2. Distribuição espacial de serpentes emplumadas em Chichén Itzá.

Podemos observar que a Grande Nivelação divide-se em dois setores: a Plaza do Castillo é mais aberto, caracterizado principalmente pela presença de estruturas piramidais. Já o Conjunto das Mil Colunas é um espaço caracterizado pela presença de pórticos e colunatas, inexistentes na Plaza anterior. As serpentes emplumadas também são diferentes em cada uma dessas áreas.

$\mathrm{Na}$ Plaza do Castillo são serpentes com plumas longas, e em forma de gancho penas que estão associadas com o poder do governante, pois aparecem em cenas de nitronização (ver figuras $1 \mathrm{~b}$ e 1c). Esta imagética está associada ao prestígio de personagens individuais e imbuídas de cenas de propaganda política. Neste sentido, acompanham sempre a imagem de um personagem conhecido como Capitão Serpente, que consideramos ser Kukulcán (MILLER, 1978; NAVARRO e FUNARI 2009). Como salientamos anteriormente, estas cenas são caracterizadas por uma parafernália de objetos usados em cerimônias de entronização do governante. 
Kukulcán aparece com traços guerreiros na Pirâmide El Castillo, sendo que atrás dele aparece uma serpente com plumas longas e barba (figuras 3 e 4). Esta representação possui algumas peculiaridades que nos fazem inferir a importância deste personagem: está registrada no espaço mais exclusivo da pirâmide perto de duas colunas em forma de serpente emplumada que sustentam esta câmara. Além disso, as escadarias norte do edifício foram edificadas à maneira de grandes serpentes emplumadas, cujo efeito ótico que se dá nos equinócios de primavera e outono faz o espectador contemplar uma sombra em forma de corpo de serpente que se projeta em um dos costados do edifício.

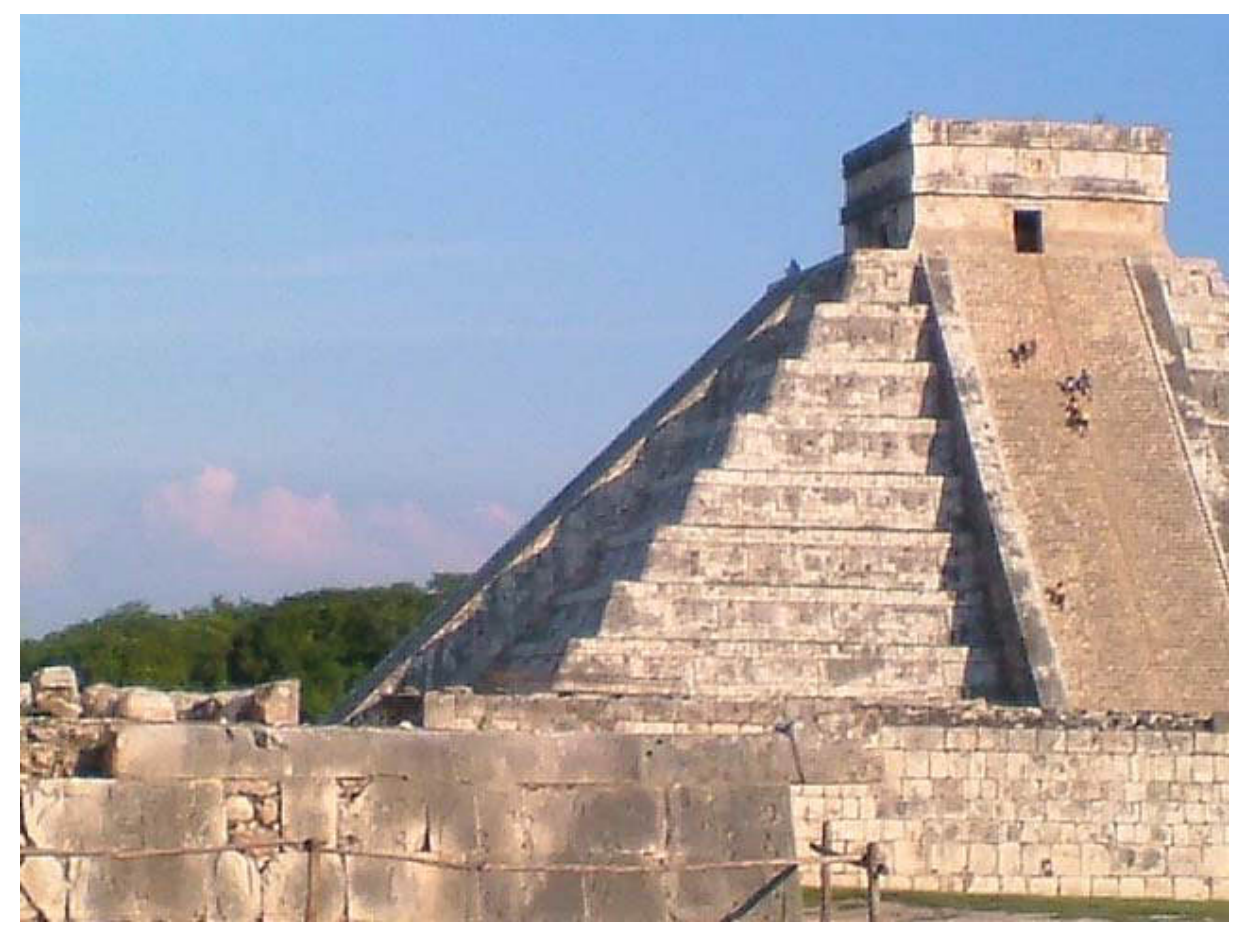

Figura 3. El Castillo. Fotografia tirada pelo autor.

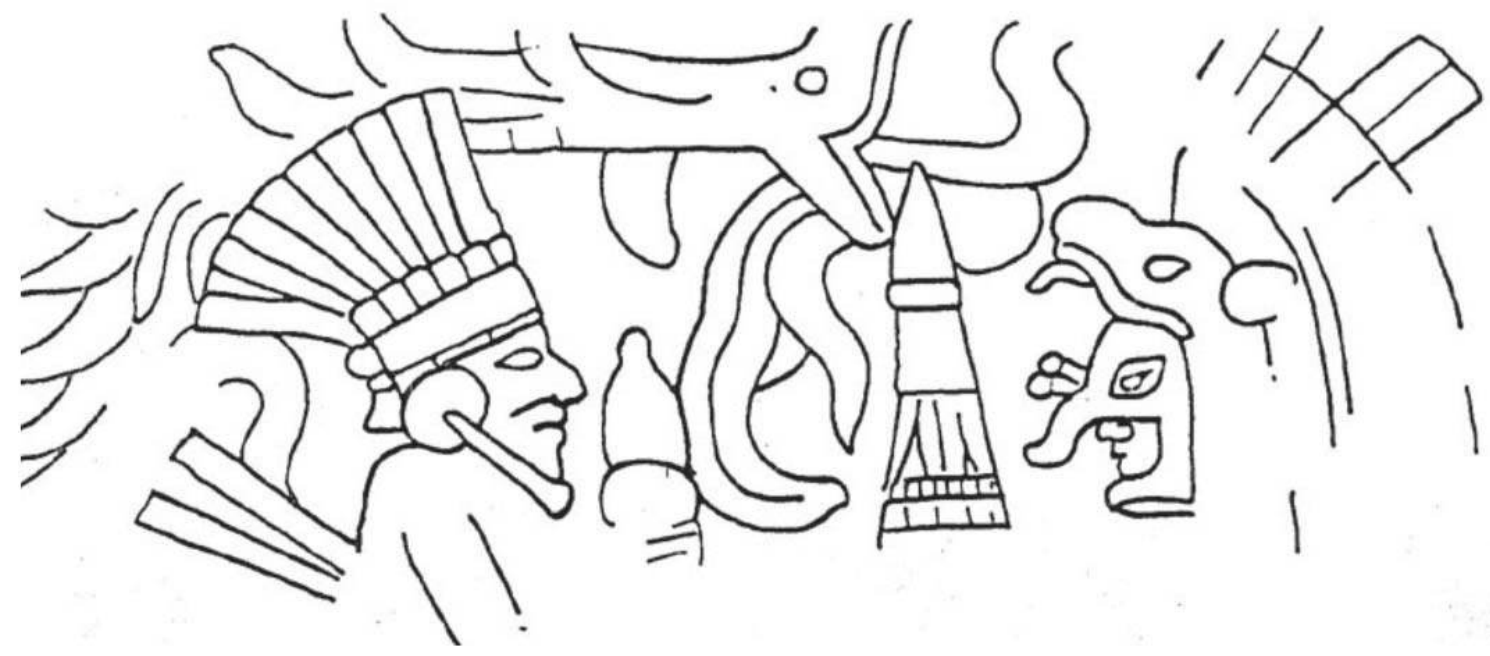


Figura 4. Kukulcán (à esquerda) aparece de frente para outro governante de Chichén Itzá. Em Taube 1992.

Já no Templo Norte, há três representações de um personagem associado à serpente emplumada (figura 4). As imagens dão conta de cenas que retratam um personagem que está sofrendo o processo de entronização. Este indivíduo leva uma serpente emplumada atrás de si. É provável que se trate, portanto, de Kukulcán sendo entronizado; o Templo Norte pôde ter isso o local deste processo ritualístico.

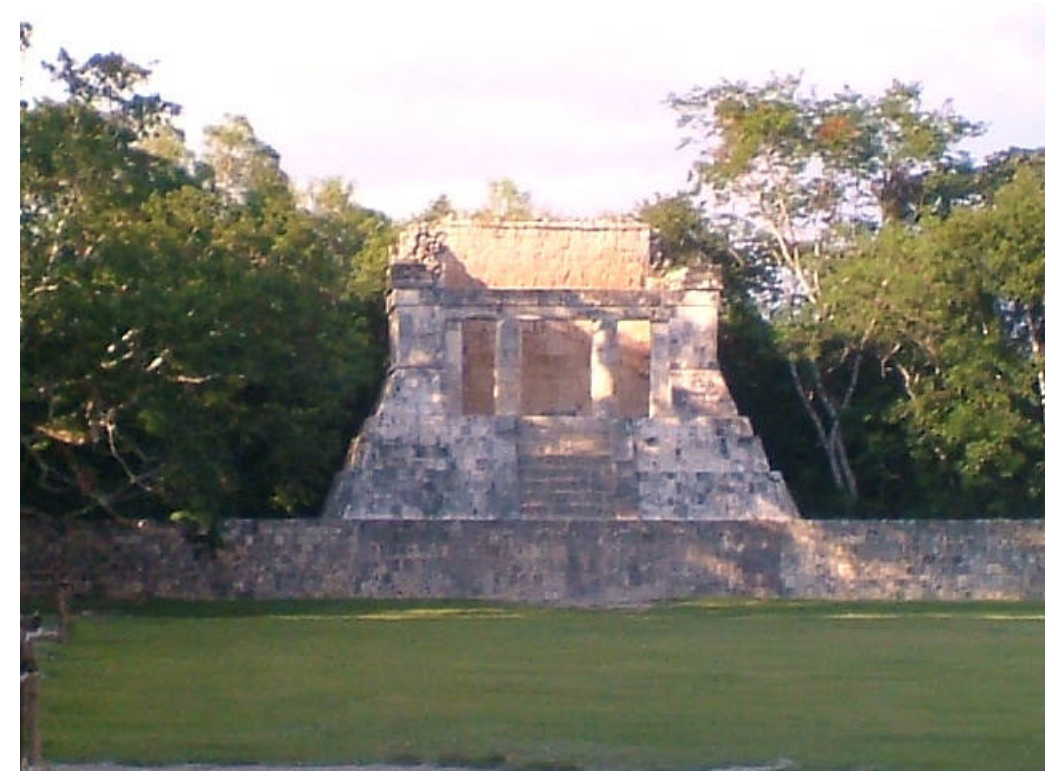

Figura 5. Templo do Norte. Fotografia tirada pelo autor.

No Templo Superior dos Jaguares, Kukulcán possivelmente é o destaque na iconografia. Os murais do edifício estão profusamente decorados e existem várias imagens de serpentes emplumadas. O destaque das cenas são as aparições de Kukulcán junto com um personagem associado a um Disco Solar, que, na literatura é conhecido como Kakupacal, outro governante da cidade de Chichén Itzá. Parece que estes dois indivíduos estão fazendo negociações de poder ou estão em rituais que passagem de poder de um soberano para o sucessor (NAVARRO e FUNARI, 2009). Além disso, há que ressaltar que colunas em forma de serpente emplumada também aparecem no vestíbulo do edifício (figuras 6). 


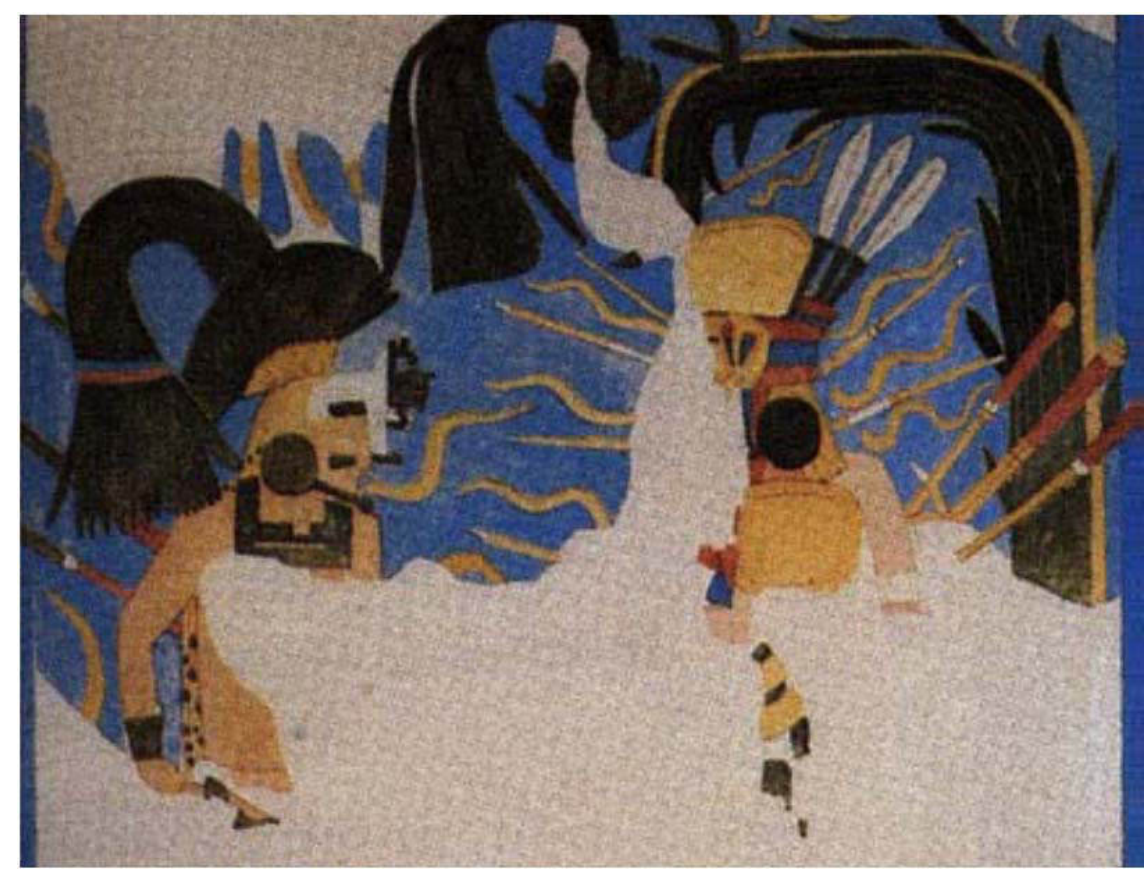

Figura 6. Kukulcán, à esquerda da imagem. Coggins, 1989: 162

Já no Grande Jogo de Pelota de Chichén, o maior da Mesoamérica, com 168 metrps de comprimento por 70 de largura, as serpentes têm plumas longas e são recorrentes na escultura, onde aparecem rematando todo o edifício. No Tzompantli e na Plataforma das Águias e Jaguares as serpentes com plumas longas aparecem nas molduras superiores e alfardas dos edifícios. No primeiro, a iconografia aparece assocaida à cenas de prisioneiros decapitados e cabeças troféu.

Além da iconografia, existem algumas evidências arqueológicas que nos levam a inferir que estes personagens que aparecem associados com as serpentes emplumadas fazem alusão direta a Kukulcán. Há que considerar a distribuição espacial dos edifícios onde a imagem está representada: são espaços destinados à elite, são fechados, com acesso exclusivo, e têm alto status social já que são profusamente decorados. Além disso, estão associados a espaços sagrados, como é a quadra do jogo de bola que se localiza em suas proximidades. $\mathrm{Ou}$ seja, são espaços destinados à atividade administrativa e rituais em Chichén Itzá.

Outro aspecto que deve ser explorado é a natureza destas construções piramidais. Considerando que a iconografia destes edifícios exploram a entronização dos governantes, e, neste caso específico, a de Kukulcán, isso poderia explicar a alta proporção de serpentes de plumas longas e de gancho representadas nestas estruturas.

Agora nos reportemos ao outro espaço adjacente, o Grupo das Mil Colunas. Este espaço também foi construído durante a época da Plaza do Castillo, mas se distingue daquela por ser espacial e arquitetonicamnete organizada de forma diferente. Este espaço é 
caracterizado pela construção de conjuntos de colunas, que não existem na Plaza del Castillo, e as imagens da serpente possuem forma de espinho, associados a uma procissão de guerreiros que caminham em fila indiana em direção a uma oferenda no centro da imagem. No Templo dos Guerreiros, por exemplo, a imagem de serpente com plumas em forma de espinho é caracterizada por cenas de guerreiros que navegam no mar e capturam prisioneiros. Estas serpentes aparecem associadas à cenas de sacrifício, onde o sacrificador retira o coração da vítima que está sobre uma pedra sacrificial.

A Serpente Emplumada da Subestrutura do Templo dos Guerreiros é notável por duas razões (Figura 1e). Primeiro, por causa do seu tamanho: tinha oito metros de comprimento e foi pintada de amarelo sobre um fundo vermelho na parede leste do edifício. Segundo, a imagem possui uma pata com garras de aves. Estas serpentes também podem ser encontrados nas páginas 3 e 10 do Códice mixteco Nuttall (Figura 7). Segundo Fähmel Beyer (2001: 191), estas serpentes estão relacionadas com o aparecimento de um cometa e estão associadas a maus presságios.

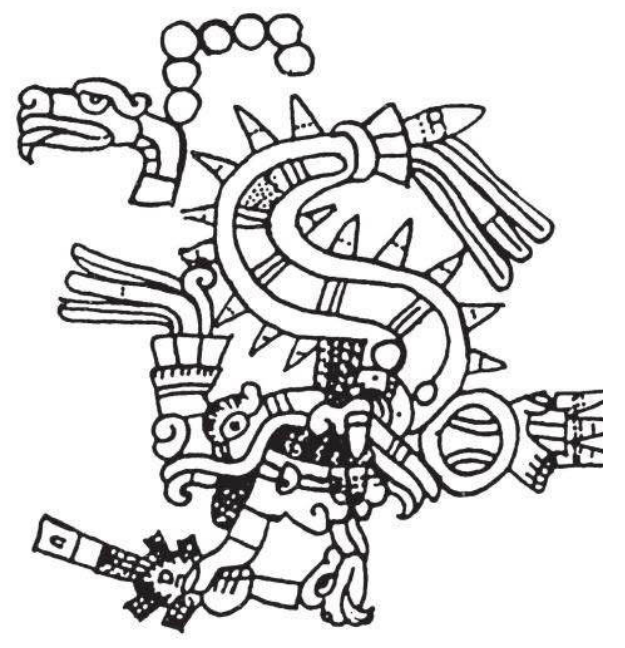

Figura 7. A Serpente Emplumada no Códice Nuttal Em Fähmel Beyer 2001, p. 206.

Segundo Fähmel Beyer (2001: 192-193), para muitos povos mesoamericanos a visão de um cometa foi vista como uma previsão da morte de um príncipe ou rei. De acordo com este investigador, no túmulo 2 de Mitla foi enterrada uma pessoa importante, em cuja antecâmara havia a imagem de um cometa. Embora na Subestrutura do Templo dos Guerrerios não haver nenhuma sepultura, a imagem da serpente com pluma em forma de triângulo isósceles pode estar indicando que a construção original do prédio foi relacionada a 
qualquer evento ou ocorrência relacionada com o presságio de um cometa. Contudo, não há nenhum estudo publicado sobre este tema em Chichén Itzá.

De acordo com os estudos de Fähmel Beyer (2001), a representação do Códice Nuttal refere-se à passagem do cometa Halley, no ano de 912 d.C. Se esse fenômeno foi visto por vários grupos na Mesoamérica nesta data e relacionado a maus presságios, faz sentido que a serpente emplumada retratada na parede leste da Subestrutura do Templo dos Guerreiros poderia, também, estar associada a tais eventos. Dado a cronologia da construção da Grande Nivelação, é mais provável que tal evento estivesse assoaciado a uma passagem anterior do cometa, ou seja, 76 anos antes, em 836 AD. Assim, o início da construção desta Subestrutura pode ser datada para esta época, provavelmente.

Ainda com relação ao complexo do Templo dos Guerreiros há que se pontuar algo importante. É uma representação de uma serpente emplumada com cornos ou chifres, dando a forma a duas colunas que davam sustentação ao teto do edifício (figura 8). Embora associada a seres míticos, a observação biológica da espécime, faz considerar que é uma cascavel da espécie Crotalus Cerastes, que não existe na península do Iucatã. Esta espécie habita os atuais Estados da Baja Califórnia e Sonora, no México e no sudoeste dos Estados Unidos, nos Estados da Califórnia, Arizona e Nevada (CAMPBELL e LAMAR, 2004 e comunicação pessoal com o Dr. Oscar Flores Villela) (Figura 9). É uma cascavel bastante venenosa. Pode ser que Kukulcán tenha utilizado toda essa variedade de cascavéis como metáfora de poder. Aqui vale ressaltar que a espécie Crotalus Cerastes procede do mesmo lugar onde se obtinha a turquesa, encontrada em oferendas em forma de disco no interior dos Templos dos Guerreiros. Sabemos, por exemplo, que várias cidades da Mesoamérica importaram diversos materiais para fins rituais, como as conchas importadas encontradas no Templo de Quetzalcoatl em Teotihuacan, associadas às atividades rituais (SUGIYAMA et al., 1991). Teria que se investigar a possível relação destes produtos importados, bem como o seu significado, com a obtenção de espécies como Crotalus Cerastes, ou outros animais, em Chichén Itzá. 


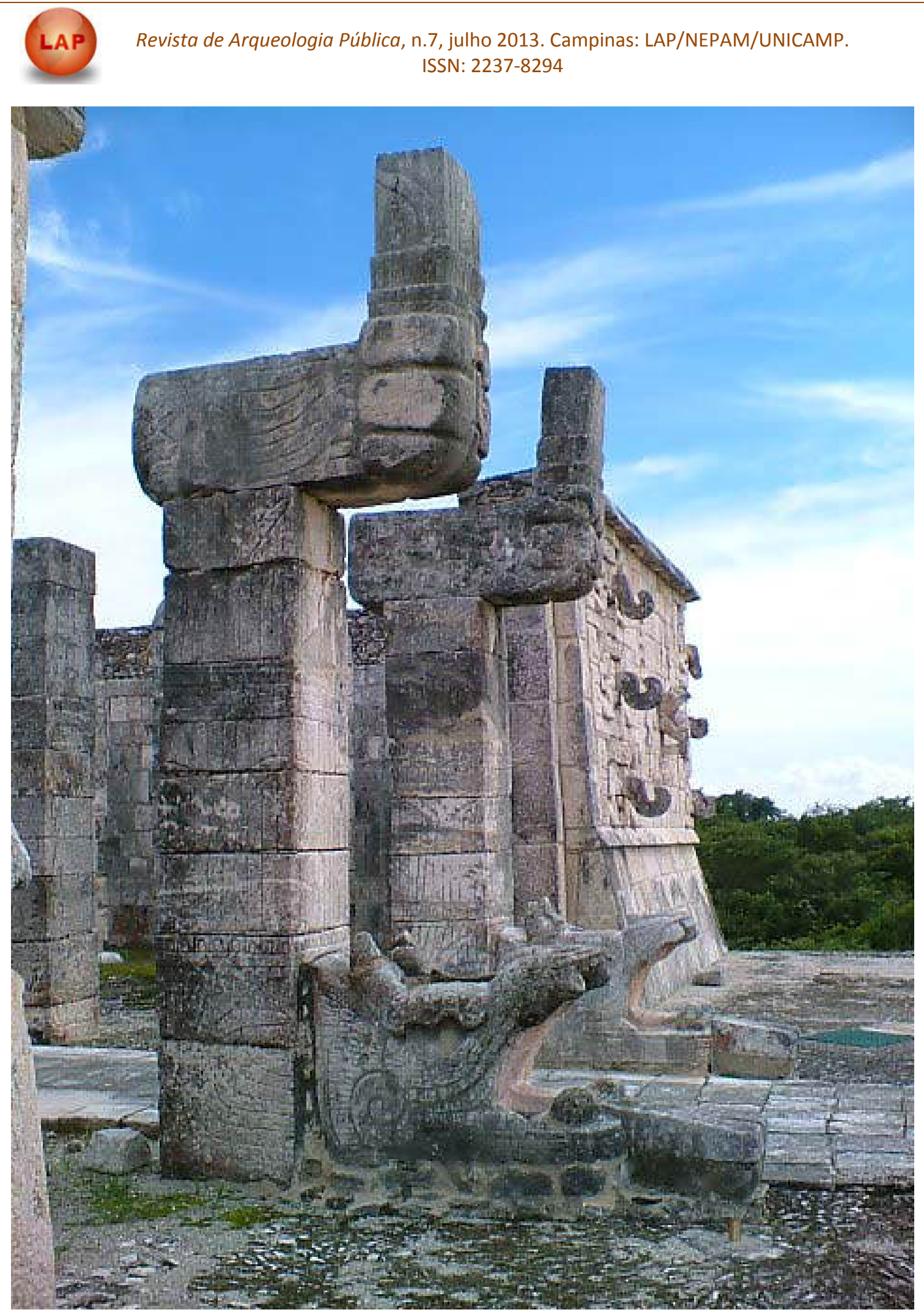

Figura 8. Serpente emplumada com chifres. Templos dos Guerreiros. Fotografia autor. 


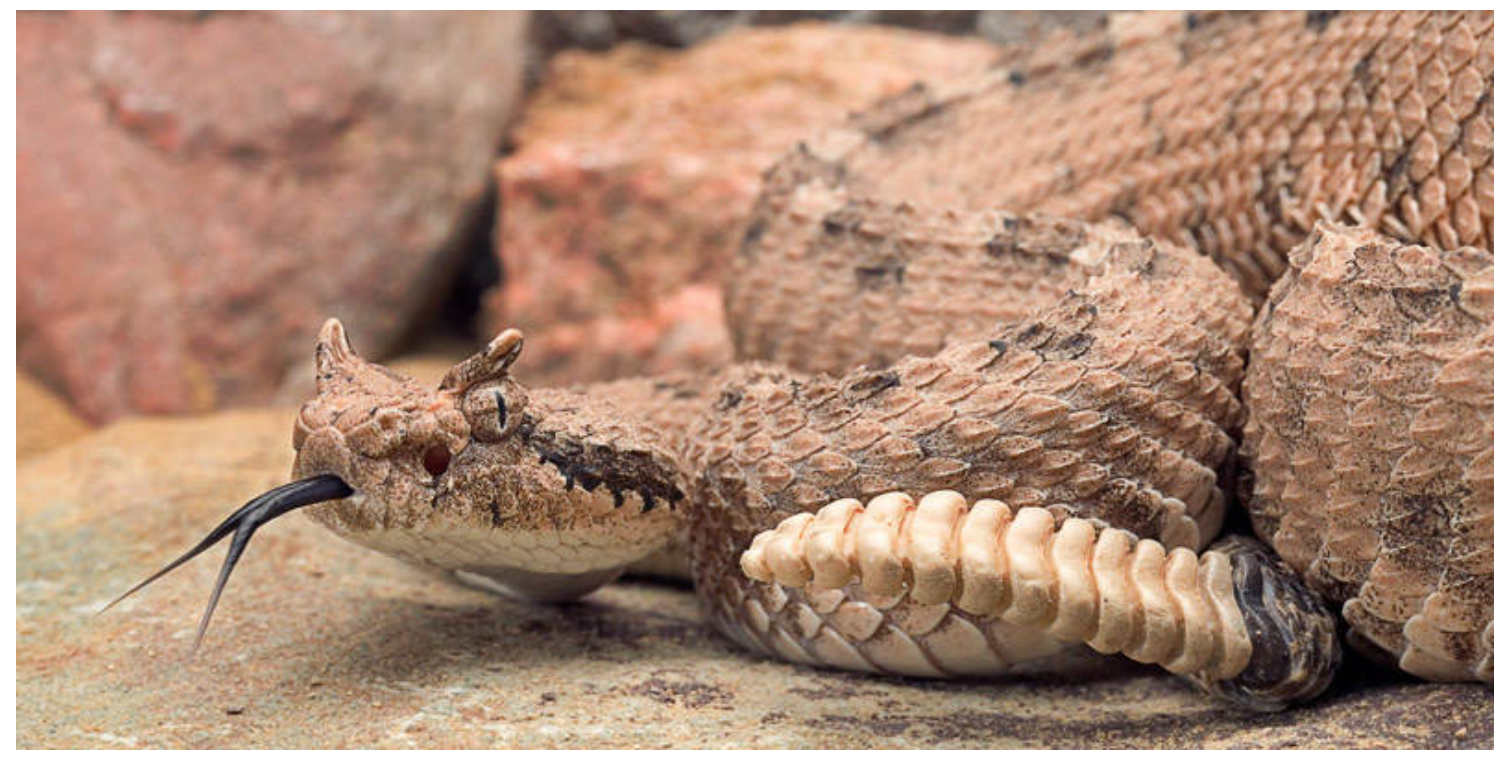

Figura 9. As Crotalus Cerastes Espécies. Foto tirada www.ontdekkingsreis.org.jpg

\section{Considerações Finais}

Uma das conclusões da nossa tese é que o nivelamento Grande não é um espaço "monolítico", como geralmente interpretado na literatura. A esplanada é dividida em dois setores principais, com uma diferença óbvia na organização do espaço e também vários elementos arquitetônicos que caracterizam cada um desses setores, que deverá corresponder a diferentes atividades sociais (NAVARRO, 2007).

A existência de uma grande quantidade de serpentes emplumadas na Grande Nivelação e sua quase ausência em outros grupos arquitetônicos, como o Complexo das Monjas e Série Inicial, indica que as imagens de serpente emplumada eram um elemento simbólico na construção da Plaza do Castillo e Grupo das Mil Colunas. São a maneira como Kukulcán metaforiza seu poder, o seno da casa real.

\section{Referências bibliográficas}

BAUDEZ, C. Una historia de la religión de los antiguos mayas, UNAM, México, 2004.

COBOS, R. The Settlement Patterns of Chichen Itza, Yucatan, Mexico. Ph.D. disertación. Department of Anthropology, Tulane University, 2003.

DE LA GARZA, M. Relaciones histórico-geográficas de la Gobernación de Yucatán. México: Universidad Nacional Autónoma de México, $1984 a$. 
DE LA GARZA, M. El universo sagrado de la serpiente entre los mayas. México: UNAM, $1984 b$.

DICCIONARIO MAYA CORDEMEX. A. Barrera Vázquez (director). Mérida: Ediciones Cordemex, 1980.

KROCHOCK, R. The Hieroglyphic Inscriptions and Iconography of Temple of the Four Lintels and Related Monuments, Chichén Itzá, Yucatán, México. Austin: Texas University, 1988.

KROCHOCK, R. Hieroglyphic Inscriptions at Chichen Itza, Yucatán, Mexico: The Temples of the Inicial Series, the One Lintel, the Three Lintels, and the Tour Lintels. Research Reports on Ancient Maya Writing 23. Center for Maya Research, Washington

D.C., 1989.

LANDA, D. de. Relación de las Cosas de Yucatán. México: CONACULTA, 2003 [1566].

LÓPEZ AUSTIN, A.; LÓPEZ LUJÁN, L. Mito y realidad de Zuyuá. Serpiente emplumada y las transformaciones mesoamericanas del Clásico al Posclásico. México: FCE, 1999.

LÓPEZ COGOLLUDO, D. Los tres siglos de la dominación española en Yucatán, o sea Historia de esta provincia, 2 vols. Austria: Akademishe Druck u. Verlagsanstalt, Graz, 1971 [1688].

NAVARRO, A. G. Las serpientes emplumadas de Chichén Itza: distribución en los espacios arquitectónicos e imaginería. Tesis de Doctorado. UNAM, México, 2007.

NAVARRO, A. G.; FUNARI, P. P. Un estudio de caso de la Arqueología Histórica: organización espacial y memoria colectiva en Chichén Itzá, pp. 163-186.

Arqueología Colonial Latinoamericana. Modelos de estudio (Juan G. Targa e Patricia Fournier orgs.). Oxford: BAR, 2009. Página de internet www.ontdekkingsreis.org.jpg

PIÑA CHÁN, R. Chichén Itzá. La ciudad de los brujos del agua. México: FCE, 1980.

RINGLE, W. M. On the Political Organization of Chichen Itza. Ancient Mesoamerica 15, pp. 167-218. Cambridge: Cambridge University Press, 2004.

RINGLE, W.; GALLARETA NEGRÓN, T.; BEY III, G. The Return of Quetzalcoatl. Evidence for the Spread of a World Religion during the Epiclassic Period. Ancient Mesoamérica 9, pp. 183-232. Cambridge: Cambridge University Press, 1998.

SHARER, R. La civilización maya. México: FCE, 2003.

TAUBE, K. The Major Gods of Ancient Yucatan. Washington D.C.: Dumbarton Oaks Research Library and Collection, 1992. 